\title{
The America Economic Crisis Of 2009/2010: Three Pillars Of American Strength That Will Lead To Recovery
}

Michael J. Provitera, Barry University, USA

Michael P. Lambert, George Mason University, USA

Maggie F. Neira, Florida International University, USA

\begin{abstract}
The notion of the Fall of the American Empire (Wojtowicz, 1993) is equivalent to the Peter Principal in that positive realization will always prevail over the negative perspective. Wojtowicz (1993) contends that Isaac Asimov wrote his foundation stories to show that every empire, even the most powerful one, has to fall eventually. Lawrence Peter (1984), an educator and hierarchiologist, argued that each manager will rise to the level in which he or she will fail. Inevitably, the Peter Principal failed because it placed a negative connotation on managerial growth. The same thing holds true with the Failure of the American Empire. America cannot fail because while there are many foundations of strength that has held America together since the American Revolution, there are three pillars that will help America continue to prosper. The three pillars are the strength of the military, the excellent education system, and the spirit of democracy that has led to capitalism. The spirit of democracy as Abraham Lincoln exemplifies as "A government of people, by the people, for the people," has kept America vibrant and open for people to rise to the highest office in the free world (Powell and Powell, 1918). In the philosophical Age of Enlightenment, John Locke, a puritan in the England of Cromwell, put forth a new civil order: law based on reason, a government deriving its power from the governed, liberty to pursue individual goals as a natural right, and private property and its use in the pursuit of happiness (Wren and Bedian, 2009). These four ideas provide the bases of how our founders designed the America of today. This paper provides an overview of the three pillars that will influence the economic recovery of America in a positive way.
\end{abstract}

Keywords: American History, Public Administration, Economic Recovery

\section{INTRODUCTION}

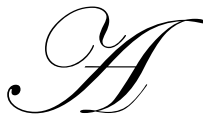

ccording to the U.S. Department of Labor Statistics, there are more than 31 million people currently unemployed---that includes those involuntarily working part time and those who want a job, but have given up trying to find one. In the face of the worst economic upheaval since the Great Depression, millions of Americans are hurting. The deteriorating transformation of the United States economy which began on January 2007 to the most recent unemployment data available today (i.e., October, 2009), places doubt on a swift recover (Egwuekwe, 2009). This article provides a sense of hope based on three pillars of prior success that made America what it is today.

The question addressed in this paper is: Why will America come out of this temporary economic crisis stronger than before? This article reviews some historical milestones of American history as it relates to wars and economic troughs. We offer a positive perspective on the current crises that America faces today and provides three pillars that will ultimately lead to America's continued success. 


\section{The Land of the Free}

The character of the people who make up our nation are without a doubt the planet's most resilient, optimistic, creative, good-natured, and a proud group of citizens bound by a common vision of an experiment we call America, the "land of the free." As Benjamin Franklin (1741) once said, "Industry, perseverance, and frugality make fortune yield."

The average American's perseverance to survive in the current economy is an example of the resilience of the American people in trying times. Companies are being downsized, salaries and benefits are being cut, and unemployment is on the rise. The housing market is down with a large amount of foreclosures being announced on a daily basis. Credit card companies are hiking the interest rates on good paying Americans, making it more difficult to obtain credit or even get out of credit card debt. The average American is making less money has had to cut back on the frills that prosperity brings, and still struggles to put their children through school and make ends meet.

On the other hand, the US has done a much better job of integrating the teeming masses flocking to our shores, yearning to be free, over the past 150 years, and the American experiment still works, despite the Patriot Act (i.e., Uniting and Strengthening America by Providing Appropriate Tools Required to Intercept and Obstruct Terrorism) that gives law enforcement authority for searches and seizures of diverse types of written and oral communications as well as personal and business records to protect against any terrorist threat to this country. The Patriot Act is both international and domestic in scope and authorizes the disclosure of financial information. While the Patriot Act has been the cause of concern by some Americans, it has prevented or circumvented terrorism to some extent. However, questions do continue to arise, for example: Is this involvement by government too much? Or after the September 11, 2001 declaration of war on the United States is this Patriot act necessary to safeguard our nation? And finally, Does the constant influx of immigrants into North America make this act necessary to keep up with what foreigners are bringing into this country?

There has always been-- for us as a nation of immigrants --this shimmering vision of being the land of opportunity, where the lowliest citizen can rise up through the ranks to wealth and power in a single generation through native talent, application, intellect, and a dollop of luck. After September 11, 2001, the US government has become more vigilant and rightfully so, after an attack on our nation's central financial hub (New York City), brought our nation to a standstill on that day, which many may have forgotten already. Just as America survived a terrorist attack at that magnitude, we will continue to strive. The next section of this article will take a brief look at the American dream and how it has been embraced by many immigrants coming to America.

\section{The American Dream}

In the last couple of decades there has been a widespread surge of immigrants attempting to migrate to America to take advantage of the American Dream. The following is a true story of one United States citizen who was once an immigrant himself. Ramirez (2009) was a great leader and one that was successful in his journey to America.

In 1979, the Sandinistas took over my country of Nicaragua and that was the beginning of my trek from Nicaragua to the United States. In July of 1982 I heard news of a mandatory military service to be instituted in Nicaragua and some of my friends and I began our plan to leave the country. I had known several families that wanted to leave the country because of the revolution. [Therefore], I organized the trip, picking up more people along the way. By August 1982, I had decided it was the right time to start the trek since celebrations for some catholic saints would begin soon and in the month of September most of the countries in Central America and Mexico celebrate their independence--what that meant was that border patrols would not be there because of these events. That was a big help considering the amount of people traveling with me. We were able to cross the borders from Nicaragua into Honduras. On this endeavor, there were women, men, and children of various ages. I organized the division of labor and instituted the rules that we all had to follow in order not to call attention to ourselves as we traveled. I also maintained our cover, when we were asked where such a large group of people were going, I answered that we were all going to a procession for the holiday to a town named Esquipulas. We maintained our route, traveling north using maps that I had acquired while I was in the military academy with Somoza's government. We managed to get 
some field worker by the name of Jornalero to help feed the little ones and some of us went into the mountains to hunt to feed the rest of us. Guatemala presented a tougher target with colder rainy weather and indigenous people that did not speak Spanish making it harder for us to communicate with them and ask for assistance but we were able to manage the situation. Once there, we rested in the border between Guatemala and Mexico in a town named Tapachula. Once in Tapachula, we decided to cross the border into Mexico during the night, hoping the patrols were not around. We made our trek towards Mexico City from Tuxtla Gutierrez with the money we had saved from our work. Once in Mexico City, most of the people contacted families in the United States to help them get across the border. At that time, I found myself alone in Mexico City, staying there for a few months. From there I made my way into California. The trip started with two people, my friend and I, by the time we got to the border with Mexico, we were around 150 people in total. My promise to them was to take them into Mexico City since I had good knowledge of the area and bus routes. Once in Mexico City most of them contacted their relatives in the United States and arranged safe passage into the promise land. While I was living in California I found some of the people that I made the trek with and they assured me that everyone made it safe into America, some of them live in North and South Carolina, California, Virginia, and Miami.

The present economy may not offer newcomers the same support that it once did for immigrants. Along with all other Americans, a lack of liquidity and access to credit may keep this new generation of immigrants from realizing the American dream to its fullest.

\section{Humble Beginnings}

Think of the humble beginnings of Lincoln, Truman, Clinton, and other leaders who rose to prominence in our country. They could never have even held the office of town dog catcher in many industrialized but stratified countries. Lincoln's modest childhood, with little schooling, in the wilderness of Kentucky, is an example of how an underprivileged American with the ambition to help his country could rise to become one of the United States greatest presidents (the $16^{\text {th }}$ President of the United States of America). Harry S. Truman, our nation's 33rd president, emerged from a modest life as a Missouri farmer, who in 1917 joined World War I, assisting in the formation of the field artillery as he was deployed to France. Upon his return, he opened up a men's retail shop in Kansas City which failed and left him on the verge of bankruptcy. However, his strong and ambitious demeanor helped him succeed into his political career. Present day Bill Clinton also came from an average middle class family. His academic excellence earned him a degree from Yale. He entered Arkansas politics and worked his way up to becoming one of the most loved and admired Presidents of the US (the 42nd ${ }^{t}$ President).

These American people may not have surfaced to their greatness if they would have been born in another industrialized yet stratified nation. Although industrialized countries may contribute to the wealth of many who work themselves up in the industrialized world, stratification of class may not allow them to emerge into the governing rule of a party. Weber's (1958) three-component theory of stratification, also known as 'Weberian Stratification' or 'The Three Class Systems' contends that power can be shown in the social order through their status, in the economic order through their class, and in the political order through their party. So class, status, and party are each aspects of the distribution of power within a community. Ergo, Lincoln, Truman, and Clinton as well as our current President Barrack Obama are proud examples that anyone with ambition and perseverance in this great country could make their dreams a reality.

\section{THREE PILLARS OF AMERICAN'S STRENGH}

\section{Military Service}

The first pillar of the strength of America and the reason it will emerge from this downturn stronger is that great leveler of our population---Military service. Wars have united us as well as divided us, but serving in uniform has provided each generation a clear pathway to economic opportunity and political power. For example, Bender (2009) posited that our economic woes have boosted military enrollment. The US Army Recruiting Command exceeded their goals each month from October 2008 through January 2009 for both the active-duty Army and the Army Reserve. Moreover, Asch (2009), a senior economic advisor to the Pentagon on demographic trends, argues that the enlistment models would predict there would be an increase in high-quality enlistment. 
While Americans have always come together during crisis times, this may be attributed to the increasing unemployment rate that the nation is experiencing. Young people graduating high school look up to military service as a means of not only serving their country, but also as a way of obtaining an education. Government studies have shown that for every $10 \%$ increase in unemployment, there is a 5\% increase in military recruitment. Young people are looking at the military as a possible career path with excellent benefits and a stable future - an American tradition that lives on since America's first war.

Another example of military service, is the Vietnam conflict in 1966; draftees from every level of society and of all races were thrown together in the cauldron of battle, in a war that was, in our opinion, one that needed to be waged.

One of the authors of this article once guest lectured on the Vietnam War at a history class at a university in Washington, DC. In preparation, he spent months reading every book he could get his hands on about the war. The facts of this war were overwhelming, for instance; We lost over 10,000 helicopters in the fighting there?

Dunnigan and Nofi (1999) found that helicopters were considered the "army mules" of the Vietnam War and were used widespread running many missions. The most famous helicopters were the UH-1's also known as the Hueys. Between 1966 and 1975 the Hueys accounted for 7,531,955 hours of flight. The Medevacs flew about 500,000 hours airlifting approximately 900,000 people on medical emergencies. Army officials reported 4,643 helicopters lost during the war; however, there were 6,000 damaged. These totaled about 10,000 damaged helicopters resulting in 3,000 deaths and 2,300 injuries.

The Vietnam War, as we see it now, was a genuinely just war, badly executed by the politicians however, but a just war nonetheless. Had we not drawn the line in the sand there, we feel that all of Southeast Asia and the Pacific Rim would today be Communist, and human rights would be a distant memory for millions of people.

From an international perspective, in both China and Vietnam, their forms of government changed during the $20^{\text {th }}$ century. From the Chinese monarchies and Vietnamese colonialism emerged a new communism. Japan and the Pacific Rim underwent a lesser change with a more profound western influence. After the war, America helped build Japan by sending men like Deming and Juran to help rebuild the country after the war. Deming and Juran's work attained worldwide recognition, and both received an invitation to work in Japan by the Union of Japanese Scientists and Engineers (Landesberg, 1999).

The communist failed in rebuilding Vietnam, primarily because Vietnam remained isolated from the global community and very distant from the Soviet Union. The US blockade after the war coupled with boundary fighting with China, has not allowed the economic growth and socialization of Vietnam. Lack of Western influence in industrialization and socialization has left these communist nations behind other Pacific Rim countries such as Japan.

The millions of young men drafted into service in the 1960s and 70s learned to get along. The national experience produced a generation of the tolerant, worldly, and wise leaders we have today. We happen to reject utterly the idea that the WW II generation was the "Greatest Generation." Not to take anything away from them, but they simply did what they had to do--fight fascism until it was defeated. The Vietnam soldiers fought against communism and were able to contain communism to Vietnam and China. Our current soldiers are responding to the attacks of a religious war waged on the United States on September 11, 2001. We are not fighting a country, but we are fighting terrorist groups who wish to impose a religion and a way of life to a free world.

The Vietnam generation did what they had to do by fighting and defeated an incredibly savvy and dedicated enemy in every major battle, including the TET Offensive of January 1968, and it was outnumbered throughout the war.

Karnow (1983) wrote that in 1967 a great majority of Americans had a sense of disappointment with the Johnson administration, high taxes, and the increasing casualties of the Vietnam War. This prompted the launch of the "Success Offensive" to improve public opinion that the war effort was succeeding in the fight against 
communism. The TET offensive began on the most important Vietnamese holiday, on January 31, 1968, the first day of the traditional lunar calendar. Both North and South Vietnam were supposed to have a two-day cease fire to celebrate the holiday; however, the Viet Cong launched a series of attacks on military and civilian command and control centers in South Vietnam. More than 80,000 communists took the allied forces by surprise that morning, launching the biggest military operation of the Vietnam War. The allied forces were quick to retaliate and contained the attack, killing many of the communist forces. Although parts of Asia remained under a communist regime, much of the Asia-Pacific rim was saved from communism by the war effort.

However, despite Americas best efforts, the economic postwar impact of the Vietnam War was felt in the mid70's as the estimated $\$ 167$ billion spent on the war left the US economy in debt and with double digit inflation. President Johnson refused to fund the war through increased taxation, so the debt that was incurred was high. The standard of living for many Americans during that time also declined from the boom of the 1950s. Similarly, the Iraq War could surpass $\$ 1$ trillion. Wolk (2006) contends that both the direct and indirect cost of the war will likely cost United States taxpayers $\$ 400$ billion. In 2003, Defense Secretary Donald Rumsfeld and other officials hoped that Iraq would help fund the war with its rich oil supply. So far, this has not been the case and the outlook of this happening is pretty grim.

The Post 9-11 generation is doing what it has to do, and is doing it with valor and selflessness that emulates the sacrifice of any previous American generation that went to war. However, there is a common purpose shared here that we have to emphasize. Each generation of Americans has fought nobly to preserve our way of life and the American vision of freedom for all. At the time, like all fighters who are by choice or chance at the tip of the spear, they fought to save each other and to kill the enemy and go home alive. Therefore, no one generation can lay sole claim to being the greatest--all of them are great. The only difference in the generations was the scale of numbers of people involved.

Unlike WW II, the Vietnam-era military was not segregated. It had routinely inter-mixed units of blacks from ghettoes, red necked racists, Yankee blue blood scions from Ivy League colleges, mid-west farm boys, New York sophisticates, salt of the earth working class Polish, Italian, and Irish men, all of them forced to live and work together as team. They all had to come together to survive.

As Lt. Colonel Hal Moore said in the movie (2002) "We Were Soldiers," when he spoke to his men before going into battle:

Look around you. In the 7th cavalry, we've got a captain from the Ukraine; another from Puerto Rico. We've got Japanese, Chinese, Blacks, Hispanics, and Cherokee Indians. Jews and Gentiles. All Americans. Now here in the states, some of you in this unit may have experienced discrimination because of race or creed. But for you and me now, all that is gone. We're moving into the valley of the shadow of death, where you will watch the back of the man next to you, as he will watch yours. And you won't care what color he is, or by what name he calls God. They say we're leaving home. We're going to what home was always supposed to be.

We are a great nation today because of Vietnam and its edition of the greatest generation. Take a bow, all you Vietnam-era Vets along with the rest of great Americans! Vietnam veterans should feel a part of something much larger than a police action or political conflict. So share your pride with all the other soldiers from all the previous generations.

In previous wars, the enemy was a visible determined enemy. However, in the current war, we are not battling an enemy, but a religious philosophy. We can't pinpoint the enemy as in prior wars. The enemy in prior wars was contained to the battlefield, whereas, the current enemy has infiltrated our shores and are right here on our soil. I don't blame today's soldiers from becoming more indiscriminate or fearing those who call God by the name of "Allah," as there have been several attacks on home military bases, based on creed.

ABC news (2007) showed home grown terrorism has been on a growing trend. In 2007, six foreign born Muslims were arrested and accused of plotting to attack Fort Dix and slaughter US soldiers. Moreover, according to the Washington Post (June 2009), Abdul Hakim Mujahid Muhammad, an American Muslim convert, allegedly shot 
and killed one soldier and injured another in a military recruitment center in Arkansas in what he said was retaliation for US counterterrorism policies worldwide. The recent Fort Hood attack perpetrated by Army Maj. Nidal M. Hasan was the third attack this year by antiwar radicals targeting the military on US soil. Hasan killed 13 of his fellow soldiers and injured 30. Current soldiers cannot take any chances at home or abroad. They have to fight a new type of enemy not encountered before.

\section{Public Education}

The second pillar to our vibrancy--and our future survival-- is our unfairly maligned public education system. Our education critics always find a way to sell it short, but it does seem to work, even in a time when government is subjecting it to the misguided idea of nationally uniform tests. Get any public school teacher in a private conversation on the subject of No Child Left Behind and ask what they really think of it. I suspect you will hear that they are being forced to "teach to the test."

The thought process behind the No Child Left Behind concept was based on the idea that if goals were aimed high in the educational spectrum, educational achievement would go side by side and increase as well. Differences in a teacher's educational background and teaching methods would be replaced with a unilateral, nationwide system of high educational standards measurable by a series of tests throughout the different grade levels of our nation's public schools. This simplistic approach of having a set curriculum per grade level and a measurable exam to assess the progress of the program would set a high quality standard for all schools nationwide. With learning objectives, learning outcomes and rubrics to measure the learning outcomes, programs and courses can better assess their teaching effectiveness. White (2009) found that supporters of the No Child Left Behind Act, agree with the Federal government that accountability to educational standards by all of the nation's schools will improve the quality of public education nationwide regardless of wealth, ethnicity, disability, or language.

Most teachers and teacher unions find flaws in standardized testing, and believe that adherence to these exams have prevented qualified personnel from becoming teachers. In one of the Presidential addresses, President Barack Obama mentioned to the nation that he focused on the importance of qualified teachers, not tests, to qualify students. He emphasized the need for funding so that teacher's salaries attract better quality teachers. He stressed that supplies should be funded by the educational system and not the teacher's personal income.

With No Child Left Behind, any child irrespective of their socioeconomic background would receive the same education throughout the nation. In the absence of No Child Left Behind, teachers would be empowered to teach the material required, without a measurable standard of competency to abide by, thereby, creating differences throughout the educational system.

In 2008, new regulations were added to the No Child Left Behind Law. It required schools to "provide a uniform calculation for high school graduation rates." It enabled a parent to be able to choose the school for their child as well as tutoring options available and giving the schools the funds necessary for teachers and counselors to communicate these new choices to parents in a timely manner. Advocates opposing the No Child Left Behind law disagree with a "one-size-fits-all" approach for teaching. They claim that with the current economic conditions, schools are not receiving the necessary funds to comply with the law.

American education, in spite of the now forgotten politicians who fought for desegregation, mixed the races up and gave opportunity to kids from all levels of society a start toward the American Way of Life. Social justice for all Americans is the American way. President John F. Kennedy also fought for school desegregation by introducing the 1964 Civil Rights Act. In his 1963 speech to the American people, President Kennedy addressed the nation stating:

The Negro baby born in America today, regardless of the section of the nation in which he is born, has about onehalf as much chance of completing high school as a white baby born in the same place on the same day; one third as much chance of completing college; one third as much chance of becoming a professional man; twice as much chance of becoming unemployed; about one-seventh as much chance of earning \$10,000 a year; a life expectancy which is seven years shorter; and the prospects of earning only half as much. 
Although the President was assassinated prior to the passage of the act in 1964, according to a Life Magazine (1973) article, other politicians such as Senators Hubert Humphreys, George McGovern, and Edmund Muskey supported the integrated communities to improve national education amongst all children regardless of race.

\section{Capitalism}

The third pillar of America's future success is the much-unappreciated laissez faire attitude we have historically exhibited toward the entrepreneur--an attitude that is fast-disappearing in a tsunami of misguided government regulations that seek to control ethical behavior in business. As long as we have capitalism, we will have continuous wealth, but with this wealth, we will have both saints and crooks. Compliance to the SarbanesOxley act of 2002, which mandated regulations of financial practice and corporate governance, disclosures and audit information for all businesses large and small, is key to building a strong accountable system of governance for free enterprise.

Fred Smith, the Chairman of Federal Express argues that the economy is cyclical. Through the tough economic times that we face today, Federal Express was able to remain successful by employing many managerial approaches such as but not limited to economic forecasting, teamwork initiatives, and total quality management. In a town meeting held in California on January 28, 2009, titled "Keeping America Competitive: the View from "Commerce Street," Smith outlined ways to build a better and healthier business environment through the creation of good-paying jobs across the United States of America. Part of his solutions included energy independence, tax reform, and policies to grow businesses, trade, and communities. Furthermore, Reuters (2009) posited that Smith believes that the current economic challenge will not only strengthen America but will increase America's competitiveness in the global marketplace.

If corporations do not receive the tax breaks that they need as part of a stimulus package, they will not be able to pass any financial gains down to their employees. Employees will continue receiving salary cuts, layoffs, and a reduced benefit packages that will ultimately hurt the economy more, as these people will not have the means to invest or spend. On the contrary, Smith (2008) contends that the country is going to get through this and the financial markets will stabilize but only after we go through a period of trauma and readjustment. He attributes the financial crisis to the intersection of four long-term developments: Reckless mortgage lending policies; high energy prices; mark-to-market accounting rules; and national policies that favor the financial sector over the industrial sector. Fred Smith is not alone on this issue, he is one of a group of 130 people composed of Chief Executive Officers, business owners, and financial experts that met with the Obama administration on December 3, 2009 to offer suggestions on curbing unemployment in the current economic condition at the Forum on Jobs and Economic Growth. The goal of this forum is to get the American economy back on track. President Obama will be launching a White House to Main Street tour, where the President and his group will visit communities across the country to speak with workers about ideas and suggestions on economic recovery.

Steve Odland, Chairman and Chief Executive Officer of the Office Depot attributes the slow economic recovery to a disproportionate economic hit on small businesses that are having a very difficult time. According to Odland, most small business entrepreneurs fund their businesses through second mortgages or equity lines of credit. Since regular mortgage rates have ballooned causing many foreclosures and a decline in the housing market, small business owners are unable to secure credit for any business startup or expansion. Unfortunately, President Obama's stimulus package has left small business out in the cold, so without any financial rescue, small businesses continue to file bankruptcy or remain stagnant. Small businesses owners need to find the appropriate liquidity sources to begin to create new jobs for Americans and to start and grow new businesses. There is hope; however, according to Reuters (2009), President Obama is expected to discuss extending aid to financially distraught states, encouraging energy efficiency by weatherizing buildings and using bank-bailout money for jobs. Many conservatives disagree with using bank-bailout money for jobs, contending that the left over bailout money should be used to pay the deficit. Other ideas proposed at the forum were to increase tax credits for small businesses hiring people, as well as more widespread credit availability. 


\section{CONCLUSION}

This article attempts to address the current economic dilemma that America finds itself in today. It reveals some pertinent historical milestones coupled with three pillars that have been the foundation of the America. Historical milestones are presented to show how progress has manifested over time. America was once a third world country in which only the rich could visit via large boat voyages and communicating with moss code and railroads. Today, America has developed into one of the strongest and most prosperous country and this is why many people still want to come to America. With our strong military, our expansive public school system, and our continued capitalistic viewpoint there is a great deal of hope for the idea and dream that our founding fathers had for America. An excerpt from America's Declaration of Independence is a reminder that our resilience is our own fortitude:

We hold these truths to be self-evident, that all men are created equal; that they are endowed by their creator with certain inalienable rights; that among these are life, liberty, and the pursuit of happiness. That to secure these rights, governments are instituted among men deriving their just powers from the consent of the governed. (American Declaration of Independence)

There is nothing stronger than an idea coupled with a dream. Roberts (2003) stated that "Dreams make stuff happen. Martin Luther King didn't say 'I have a business plan or a goal, or a vision, nor did Microsoft, Gates dreamed of a PC on every desk." A dream is at the heart of great endeavors.

Our American idea of freedom and the indomitable American people will see us through this economic bump in the road that we know face. We have great faith in the United States of America, and feel we will emerge stronger and better than ever in the next two years because of our greatest generation---You.

\section{AUTHOR INFORMATION}

Michael Lambert is an Executive Director for the Distance Education and Training Council. He earned a BS degree in English Education and an MA degree in English Literature from the Indiana University of Pennsylvania, and an MBA degree in Finance from George Mason University. Michael has served as the Executive Director of the Distance Education and Training Council since 1992. Over the years, he has served on more than 400 accreditation review committees in five countries. Michael also has taught, written, and lectured widely on distance education and accreditation. He served in the U. S. Army Reserve in the Quartermaster Corps as an officer, where he was responsible for distance study course development at the USA Quartermaster School, Fort Lee, Virginia.

Michael J. Provitera is an assistant professor of organizational behavior at Barry University, Miami, Florida USA. He received a B.S. with a major in marketing and a minor in economics at the City University of New York in 1985. In 1989, while concurrently working on Wall Street as a financial analyst, Dr. Provitera earned his M.B.A. in finance from St. John's University in Jamaica, Queens, New York. He obtained his D.B.A. (Doctorate of Business Administration degree) in management from Nova Southeastern University, Ft. Lauderdale, Florida in 2000. Dr. Provitera has fifteen years of Wall Street corporate experience at various investment banks. In his last position at Mizuho Financial Group, he was an Assistant Vice President of Fixed Income Operations where he managed fourteen people.

Maggie F. Neira is a Senior Account Representative in the Finance Department for Federal Express for the Latin American Headquarters. She has a Master of Public Administration degree from Florida International University. She has corporate experience in major companies such as the IBM Corporation, Hewlett-Packard, and Knight-Ridder Newspapers. She is an adjunct instructor at Barry University in Miami Florida where she teaches finance, leadership, quality and productivity. She dedicates her contribution to this article to the 1960's Cuban immigrants who fled the Castro regime into this country to exercise their right to live in the free world. Their hard work contributed to the growth and prosperity of their communities throughout the United States of America. 


\section{REFERENCES}

1. $\quad$ Bender, B. (2009). "Down Economy Boosts Military," The Boston Globe.

2. Bull, A. (2009). "Obama keeps focus on jobs, warns no silver bullet," Reuters, December 8.

3. Chambers II, J. W. (1999). The Oxford Companion to American Military History. New York, Oxford.

4. Declaration of Independence. Found on website http://www.ushistory.org/declaration/document/index.htm on January 6, 2010.

5. $\quad$ Dunnigan, J. F., and Nofi, A. A., (1999). Dirty little secrets of the Vietnam War. St. Martin Press

6. Fox News Today (2009) - transcripts - Is the recession over? Is the economy on the rebound?

7. Fox News Today, September 20. Great Schools Staff, "What the No Child Left Behind Law Means for Your Child," found on website http://www.greatschools.net/improvement/quality-teaching/no-child-leftbehind.gs?content $=61$ on December 11, 2009.

8. Franklin, B. (1744), Poor Richard's Almanac, found on website http://www.richhall.com/poor_richard.htm on January 3, 2010.

9. Harry S. Truman Library \& Museum, Biography, found on website http://www.trumanlibrary.org/hstbio.htm on January 7, 2010.

10. Hsu, S. S., "Fort Hood attack is 3rd this year by antiwar radicals targeting military on U.S. soil", The Washington Post, November 6, 2009. Found on website http://www.washingtonpost.com/wpdyn/content/article/2009/11/06/AR2009110603182.html on January 7, 2010.

11. Karnow, S. In Vietnam, New York: Viking, 1983, pp. 545-546

12. Landesberg, P. (1999). "In the beginning, there was Deming and Juran," The Journal for Quality and Participation, November/December: 59-61.

13. Office of the Press Secretary, About the White House, Presidents: Abraham Lincoln, found on website http://www.whitehouse.gov/about/presidents/abrahamlincoln on January 7, 2010.

14. Office of the Press Secretary, About the White House, Presidents: William J. Clinton, found on website http://www.whitehouse.gov/about/presidents/williamjClinton on January 7, 2010.

15. Office of the Press Secretary, the White House, "White House Announces December Date for Forum on Jobs and Economic Growth," (November 2009). Found on website http://www.whitehouse.gov/the-pressoffice/white-house-announces-december-date-forum-jobs-and-economic-growth on January 7, 2010.

16. Peter, L. J. (1984). The Peter Principle: Why things always go wrong, Bantam, $16^{\text {th }}$ edition.

17. Powell, L. P., and Powell, G.W. (1918). Patriotism through literature: The spirit of democracy, Rand McNally and Company, Chicago and New York.

18. Ramirez, E. (2009). Personal conversation during a Leadership Development course at Barry University, Miami, Florida, in Summer 2009.

19. RTTNews (Nov. 19, 2009), Senate Homeland Security Committee Launches Ft. Hood Attack Investigation. Found on website http://www.tradingmarkets.com/.site/news/TOP\%20STORY/2667677/ on January 7, 2010.

20. Simkin, J. Spartacus Educational, "the 1964 Civil Rights Act,” found on website http://www.spartacus.schoolnet.co.uk/USAcivil64.htm on January 7, 2010.

21. Smith, F. Washington is the problem. FedEx's CEO on McCain, free trade and the tax bias against capitalintensive industries. The Wall Street Journal, October 25, 2008

22. Smith, F. FedEx CEO Fred Smith addresses Town Hall LA on the Economy's Impact on Industry. Town Hall Los Angeles, February 2009

23. White, D. (2009). Pros and Cons of the No Child Left Behind Act. Found on website About.com on January 7, 2010.

24. Wikipedia, "Three Component Theory of Stratification," found on website http://en.wikipedia.org/wiki/Three-component theory of stratification on January 7, 2010.

25. Wojtowicz, S. (1993). The Fall of the American Empire. Found on website http://www.slawcio.com/republic.html on January 6, 2010.

26. Wolk, M. (2006). Cost of the Iraq War could surpass $\$ 1$ trillion, Found on website MSNBC.com on January 7, 2010.

27. Wren, D.T. \& Bedeian, A.G. (2009). The Evolution of Management Thought. $6^{\text {th }}$ edition. John Wiley \& Sons, Inc. 


\section{NOTES}

